\title{
Determinants of Business Networking Behaviour of Women in Small Businesses
}

\section{ABSTRACT}

The purpose of this study was to investigate the association between the networks and networking behaviour of women small business owners (SBOs) and business/owner characteristics including: industry sector, industry experience, educational background, and family responsibilities. These are some of the most common factors influencing women's businesses as identified by the literature. The chosen methodology was case study, which included a variety of data sources: observations, questionnaires, and interviews. Initial analysis of the data from the interviews and observations has shown that industry sector, industry experience, and family responsibilities directly impacts types of networks and networking behaviour of women SBOs. Whereas education or training programs in the same field as the participant's business, does not directly influence their networking behaviour.

Keywords: Small business, Women SBOs, Networks, Networking behaviour.

Effective networking is one of the easiest ways to promote a business. It is an essential part of being a business owner, and one of the best ways to find new clients, new business opportunities, potential suppliers, and business alliances (McClelland, Swail, Bell, \& Ibbotson 2005; Stanger, Roffey, Forsaith, McInnes, Petrone, Symes, \& Xydias 2002; Wesman 1995). Both social and business networking is important for SBOs as it can increase the success rate of their business (Birley \& MacMillan 1997; Carter \& Evans 2006). A business network is defined as the linkage between different enterprises whereas a social network is defined as the linkage between defined groups of connected people (Wharton \& Brunetto 2007). For the purpose of this paper, the word network refers to both social and business networks.

Many researchers such as Conway, Jones, and Steward (2001), Greve and Salaff (2003) and Nijkamp (2003) conclude that networks help small businesses in their acquisition of information and advice, and assist business owners to supplement internal resources. Business networks are crucial for SBOs to compete in competitive markets and can lead to development of innovative products. Carter and Evans (2006) and Birley and MacMillan (1997) maintain that extensive, diverse and complex business networks are more likely to provide business owners with opportunities; increase their chances of solving problems; and ultimately giving them a better chance for business success. Conversely, for many women SBOs a lack of networking and limited access to high profile social and business contacts can have negative implications for their capacity to grow and further develop their business (Lake \& Erwee 2005; Neergaard, Carter \& Shaw 2006). 
This research examines the link between personal and business characteristics of women SBOs with the intention of exploring the links between these and networking. It provides a review of the current literature on women in small business and draws together four areas of study - namely: industry sector, industry experience, educational background, and family responsibilities, and the impact of these linked and dependent factors on the networks and the networking behaviour of women SBOs.

\section{NETWORKS AND NETWORKING}

All economic transactions are embedded in networks of relationships (Granovette 1985). SBOs, surrounded by fluctuating networks of social and business relationships, are unlikely to make decisions in isolation (Johannisson et al. 1994 cited in Shaw 2006), as they pursue economic and noneconomic goals (Granovetter 1992). Networking is one of the easiest ways for SBOs to acquire crucial business information and resources (Nijkamp 2003; Wiklund et al. 2009).

Business owners build networks that continually change, with business owners systematically analysing the individuals within their networks, and the time spent networking (Greve \& Salaff 2003). Women SBOs are most likely to be in unincorporated, home-based businesses, working alone (Breen 2010; Redmond \& Walker 2010; Thompson, Jones-Evans, \& Kwong 2009). Home-based SBOs are more isolated both socially and from access to information because they have no links to a parent organization. Hence, they have greater need to forge local social and business networks to access information, advice, support, and infrastructure (Mason et al. 2011).

Studies conducted in Australia and overseas have found gender differences in the networking behaviours of men and women SBOs (Klyver \& Terjesen 2007; Robson et al. 2008; Sorenson et al. 2008). Women SBOs are more likely to have homogenous networks (Renzulli, Aldrich \& Moody 2000), and use informal family network contacts (Dawson et al. 2011; Robson et al. 2008). Overall, only a small portion of women SBOs join formal networks in search of business opportunities, because such formal networks are not based on trusting relationships formed over a period of time (Wharton \& Brunetto 2007). Many women SBOs prefer to network with other women, and women only networks are seen as an important feature for them (Dawson et al. 2011; Hanson \& Blake 2009). This gender bias can work against most women SBOs as women are underrepresented in key 
industries, such as finance and banking, which are important for business success (Still \& Timms 2000).

Additionally, some women SBOs tend to impose self-restriction on their networks, due to their own actions, views, and decisions to network (Gamna \& Kleiner 2001). This may be because they do not feel comfortable in male-dominated networks, and/or prefer communicating with other women, and/or may be the result of a sense of exclusion from male dominated networks, or because they have a specific requirement such as developing management skills (Dawson et al. 2011).

The following sections reviews the factors, as identified by the literature, that potentially impact women SBOs' networks, exploring the links between each factor and networking behaviour of women SBOs.

\section{INDUSTRY SECTOR}

Traditionally, there has been a high concentration of women in the services and retail business sectors (Bennett \& Dann 2000; Ucbasaran, Lockett, Wright \& Westhead 2003). Many service and retail businesses require little start-up capital, are not labour intensive, and allow women SBOs to operate from home and/or on limited hours (McClelland et al. 2005; Still \& Walker 2003; Winn 2005). Many women SBOs limit the extent or size of their business, deliberately keeping the business small so they can manage their various domestic commitments (Stanger 2004).

Previous researchers (McClelland et al. 2005; Shabbir \& Gregorio 1996; Stanger 2004; Winn 2005) have identified a direct link between gender and the nature of the business or the industry itself, and a direct link between the industry, business operation, and SBOs' networks. For example, Sappleton (2009) suggests women who operate firms in traditionally female sectors have the highest levels of social capital, whereas those working in traditionally male sectors have lower levels of social capital, measured in terms of trust, community engagement and social networks. Hence, there is a link between industry sector and the networking behaviour of the business owner. This article seeks to further explore the influence of industry experience on the networking behaviour of women SBOs.

\section{INDUSTRY EXPERIENCE}

Industry experience is considered to be one of the key factors for business success (Kwong, Thompson, Evans \& Brooksbank 2009; Roffey, Stanger, Forsaith, McInnes, Petrone, Symes, \& 
Xydias 1996). Brush and Hisrich (1991) found that the three vital factors for business survival are: skills, knowledge, and networks of the business owners. These three crucial factors are shaped by industry, workforce knowledge, and experience (Brush \& Hisrich, 1991).

On the whole, men gain more industry and business experience and knowledge before starting their own business, compared to most women (Baptist, Sanders, Conroy \& Norris 2006; Brush 1992; Fagenson 1993; Stanger 2004). Whereas women may have had some industry and general work experiences, they may not have had managerial experiences in the industry (Brush \& Hisrich 1991; Roffey et al. 1996; Winn 2005). Overall, women have less work or industry experience, often due to having less time in the workforce, partly because women are the primary care provider within the family (Smith, Smith \& Hoy 1992; Walker, 2002). Traditionally women are less likely to inherit a family business or to have been in a position of authority in that business. Gender based labour markets and withdrawal by women from the workforce, due to child care responsibilities, limit women's ability to build business skills and resources needed for establishing and operating a business (Fischer 1992; Roffey et al. 1996; Walker 2002).

Several authors (Bennett \& Dann 2000; McClelland et al. 2005; Winn 2005) have identified the influence of industry experience on the networking behaviour of business owners, and the reasons why women are more likely to be disadvantaged by a lack of relevant industry experience (Chun, Barrett, St-Onge, Firdausy, Lee, Zabludovsky, Tiong-Aquino, Lai \& Weeks, 1999; Dhaliwal 2000; Kwong et al. 2009). This paper seeks to further demonstrate the direct impact of industry experience on the networking behaviour of women SBOs.

\section{EDUCATIONAL BACKGROUND}

Whereas some researchers (Stanger et al. 2002; Roffey et al. 1996) have found no direct link between formal education and business success, others (Bates 1995, Gray 1999; Robertson 2003) suggest that the business owner's level of education does impact on their business venture, and those with higher levels of education are more likely to achieve financial success. Furthermore, the type of industry that SBOs get involved in, are related to their educational levels (Gray 1999).

Studies undertaken in Australia and other western countries such as UK and USA (Bennett \& Dann 2000; Buttner 1993; Dana 2001; Dann, Bennett, Drennan, \& Dann 2006; Still \& Walker 2006), found 
that most middle class urban women business owners from European backgrounds have higher levels of education than their male counterparts. However, women SBOs are more likely to lack finance, marketing and management skills. Furthermore, the education of these women may not be industry related or directly related to business activities (Roffey et al., 1996).

Although some of the reviewed literature suggest that there is no direct link between formal education and business success, (Stanger et al. 2002; Roffey et al. 1996), they fail to explain the influence of formal education on the networking behaviour of business owners (Stanger et al. 2002). Brereton and Jones (2002) found that formal education such as an MBA, does contribute to the networking ability of the entrepreneurs. Given the limited research on educational levels and networking behaviour of entrepreneurs, it cannot be definitively concluded that formal educational does have an impact on the networking behaviours of entrepreneurs and business owned managers.

\section{FAMILY RESPONSIBILITIES}

The vast majority of studies regarding family responsibilities have shown that regardless of culture or the level of involvement in business activities, women are more likely than men to perform domestic duties, and shoulder the child care and family responsibilities (Ahl 2006; Low 2008; Walker \& Webster 2007). The majority of research suggests that balancing work and family responsibilities is one of the major motivational factors for women to start their own business (Dann et al. 2006; Heck, Rowe, \& Owen 1995; Hughes 2006). This often lead to women having to combine their work duties and home responsibilities, limiting the scope of the business, and the time available to engage in business activities (Allen \& Truman 1991; Dhaliwal, Scott \& Hussain 2009; Walker, Wasserman \& Welman 1993). Furthermore, many businesswomen find it difficult to separate personal life and their work (Heck et al. 1995; Kraut 1988). Additionally, women and children within the family often provide cheap or free labour and assistance to male business owners, whereas female business owners are less likely to draw on family labour (Carr 1990; Chiu 1998). So for women SBOs, family responsibilities and domestic duties have a potential negative impact on their business operation, including their networking activities, thus reducing the chances of business growth, and the ability of the business owner to achieve their financial goals.

\section{METHODOLOGY}


The overarching research question for this study was:

"How do personal and business characteristics of women SBOs influence their networking behaviour?

There were four dependent variables in this study: industry sector, industry experience, educational background, and family responsibilities. The types of networking activities were categorised into formal and informal networking. Formal networks included: attending formal business functions such as seminars, conferences and networking functions organised by government agencies and/or business agencies. Informal or social networks/networking included family, friends, previous colleagues and employers.

The aim of the research was to determine how the four factors influence the size of the participants' networks, mode of communication between the owners and the actors within their network, and how frequently they were used, and participants' preference for formal or informal networking. The research was guided by social network theory, which is the study of how the social structure of relationships around a person, group, or organization affects beliefs or behaviours (Hatala 2006).

The research was best suited to a case study research approach, because the topics being investigated were both objective and subjective in nature. Observations, questionnaires and one-to-one semistructured in-depth interviews were used as the data collection method. In this research there were 28 individual cases of women SBOs, which were then grouped together as the study of the networking behaviour of women SBOs in Perth, Western Australia.

The first phase of data collection was observations. Prior to recruiting participants for the study, the researcher attended five formal networking functions organized by various government and private agencies. During these functions, the researcher observed the networking behaviour of women attending these functions. The researcher then approached and struck up a conversation with potential research participants. This allowed the researcher to observe these women's style and mannerism when approached by a stranger during a networking function.

The second part of the researcher's observation occurred at the time of interviews. These observations enrich the data collected because they tapped into the valuable non-verbal communication that occurred during the interviews. 
In the second phase of data collection, questionnaire were used to ask participants identical questions in the same order regarding their industry, years of experiences within the industry, educational levels, relationship status, and number of dependents. The response categories from which participants choose were predetermined and fixed. The advantage of this inflexibility was that it allowed for meaningful comparison of responses across participants.

The third and final phase of data collection was the semi-structured one-to-one interviews. The interview questions incorporated sections dealing with respondents' attitudes to networking within and outside their immediate communities. The interview questions explored: the actors or individuals within the participant's network; links or the relationship between the participant and the individuals within the network; flow or the exchange of information that occurred between the participants and the actors within the network; and the mechanism or the mode of interaction used by the participants and the actors.

The questions for the questionnaires and the interviews were based on the literature review and the research question.

A purposeful sampling approach that included variables such as: industry and industry experiences, educational levels, and family responsibilities were designed. The sample was drawn from a range of sources including: the Small Business Development Corporation; Business Enterprise Centres, the Women's Economic Development Organisation; and The Rural, Regional and Remote Network; and personal contacts. Furthermore, the participants were able to recommend other potential participants for the research resulting in snowball sample. This allowed a good mix of business women who were members of formal business organisations, business networking associations, and women who were not involved with any formal associations.

\section{RESULTS}

\section{INDUSTRY}

Networking behaviours of participants without dependents, was mainly based on the nature of their business. Participants in upper tier or professional industries such as IT, Management, and Telecommunications did attend business functions and meetings, even if they preferred not to, because their businesses demanded it. 
The nature of the business also determined whether the participants took part in mixed gender networks or not. For example, women in male dominated industries were more likely to network in mixed functions, but often expressed uneasiness while attending them. Furthermore, these participants were more prone to experience credibility issues. For example, one participant stated:

I don't often experience credibility issues, but definitely with some men. I would say that in my three years that I have been in business it might be two or three individuals that I would have a problem but I don't deal with them now.

Credibility issues for participants in male dominated industries were more prominent for younger participants, in their twenties. None of the participants in female dominated industries, such as health services, children services, and education services, had experienced credibility issues with their direct customers or suppliers. However, all participants had experienced some form of discrimination when starting the business. Most believed that they were not taken seriously because of their gender. The issue was summarized by one of the participants:

I don't think banks take women businesses very seriously. I still think that they think that we are weaker gender and that we don't understand business.

These findings complements other research that also indicate women SBOs are still not being taken seriously by business advisors, including banks and financial institutions (Still \& Walker, 2006). However, the research goes further by identifying that industry sector itself is a determining factor in the level of discrimination from various stakeholders. For example, women in health services industries are less likely to encounter credibility issues by their customers, whereas technical abilities of women in IT industry are more likely to be questioned by the customers.

The industry was also an important factor into whether the participants networked internally and utilized their employees' networks to gain competitive advantage. In this research employees failed to emerge as meaningful constituent parts of the networks of the individual SBOs in the study. Only Participants in IT industry exploited their employees' networks to benefit the business. This finding can be explained by the competitive nature of the small business sector. Most of the businesses in this research operated in a high competitive, low trust environments. Many of the participants who did employee full time staff, with the exception of those in IT, did not share business information with 
their employees, for concern that their employees might use the information to setup their own businesses.

The participants' criteria to identify a major client were dependent on the nature of the industry. Participants in upper tier services such as: IT and telecommunications, health, finance, project and management sectors, used two criteria; one the size of the account and how much the client contributed directly to the business's turnover; and second, whether they added to the prestige and reputation of the business. In these industries, prestige and reputation were recognized as a critical asset, especially for the purposes of supporting their acquisition of referral and new business. The participants in the other industry sectors only used the clients' direct economic distributions, as the criteria to identify them as a key client.

Rather than seeking to personalize relationships with all clients, women SBOs engaged in relationship marketing and sought to personalise relationships with their major clients for purposes of securing a stable client base, rather than investing in formal marketing strategies. They networked actively only with those clients identified as being able to contribute directly or by reputation to the success of their business. The participants believed it made economic sense for them to maximize and concentrate their networking efforts, on those clients most likely to generate repeat and referral business. In this way, they used their limited resources most effectively.

\section{INDUSTRY EXPERIENCE}

The participants were asked about their previous work and why they had chosen their particular business. The aim of these questions was to determine if the participants had any relevant industry experiences. Relevant industry experience is one that is specific to the industry of the business owner. Fourteen of the participants stated that they had worked in the industry before, and this had helped them establish their businesses. These participants also stated that having the industry know how helped them identify the best networks, and networking activities for their business. These participants had a network of people or right contacts that helped their business, were members of specific organisations or groups, and only attended certain business functions.

Participants networking behaviour was not only dependent on their previous industry experience but also the phase of their business. In the early stages of the business, the participants had the smallest 
networks of discussion partners. During the planning phase for their new business, eight of the participants said they did not know who could help them, and this increased the number of activities, and these participants expanded their business by contacting a large set of people and associations who could help them. However, 50\% said they did not seek out help either because of the low skill requirement of the business or because they had worked in their chosen industry, knew key persons within their industry that could provide them the required support and resources. Once the business had been established, the number of relationships within the networks became smaller, and the participants reduced the size of their networks, concentrating only on those who continued to provide them the necessary support and resources.

\section{EDUCATION}

In this study, the sample had reached high levels of educational attainment, with more than half having tertiary qualifications and a quarter having postgraduate qualifications.

Twenty two of the participants had some form of qualified education, with sixteen of the participants' qualifications being relevant to their business. The participants with relevant qualifications to their business said that their qualifications increased their business credibility with different stakeholders.

Depending on the industry, business related formal education was specifically important to those operating from home. Furthermore, these business operators ensured that their customers were aware of their formal qualifications, displaying their qualification certificates in their home offices, and printing the details on their business cards. However, formal qualifications, whether relevant or irrelevant to the business, failed to influence the networking behaviours of the participants. Their qualifications did not make them more or less active in networking; influence their preferences on networking or how they networked. The participants without formal qualifications believed that they needed to attend training workshops, such as accounting, marketing or finance, to improve their business skills, but their networking behaviour was dependent on their family responsibilities or the nature of their business.

Even though at first glance, the findings in this research suggest that formal education or qualification of women SBOs fail to directly alter their networking activities, a more detailed analysis of the information, showed that sixteen of the twenty two participants formal education was related to their 
business, and hence their chosen industry. Industry had a significant impact on the networking behaviour of the participants. Hence, it can be concluded that formal education does have an indirect impact on the networking behaviour of the participants.

\section{FAMILY REPSONSIBILITIES}

There were two categories for relationship status; single, or with a partner. The majority of respondents, (21) were either married or in a relationship. Over $43 \%$ or 12 of the respondents did not have dependents. About $36 \%$ or 10 of the respondents had two dependents that were children under the age of 18 . Over $21 \%$ or 6 of the respondents had one child under the age of eighteen. None of the respondents had more than two children.

The influence of family and parental role on networking behaviours was apparent in the sample. Family and domestic responsibilities were the most common reasons given by participants with dependents, for not attending formal business functions or preferring informal business discussions with friends, acquaintances, and business associates. As stated by one of the participants:

Networking is taking time away from either being here in the business and doing what needs to be done or if it in the evening it is taking time away from my family.

The networking behaviour of participants without dependents was mainly based on the nature of their business.

These findings complement earlier researches that highlight the importance of marital status and caring for family members for business women (Carter \& Shaw 2006; Humbert \& Drew 2010; Kim \& Ling 2001). Even as a business owner, many women continue to assume multiple roles in the family, being responsible for household chores, childcare, and parent care. This often led to women having to combine their work duties and home responsibilities, limiting the scope of the business and the time available for engaging in business activities (Allen \& Truman, 1991; Dhaliwal et al., 2009). As shown in this research, for women SBOs, family responsibilities and domestic duties have a negative impact on their ability to engage in formal networking activities.

\section{CONCLUSION}

Industry sector, industry experience and family responsibilities had a direct impact on the networking behaviour of women SBOs. Family and domestic responsibilities were the biggest factor influencing 
the networking behaviours of participants with dependents. Whether the participants networked through formal or informal mechanisms or both depended on industry sector, and family responsibilities. Participants in male dominated industries were more likely to network in mixed functions, but often expressed uneasiness while attending them.

Specific and relevant formal education or training programs, such as business and management certificates, or education or training programs in the same field as the participant's business, did not directly influence their networking behaviours. However, formal education was related to the participants' choice of industry, and industry had a significant impact on the networking behaviour of the participants. Hence, it can be concluded that formal education does have an indirect impact on the networking behaviour of the participants.

A notable limitation of this research is that had limited sample selection to women living in Perth, Western Australia. How different they are as a population to women in other parts of the country requires further research. Finally, due to restrictions on time and resources, the research was cross sectional rather than longitudinal. Hence, the research was only a snapshot of the current business attitudes and behaviours and did not measure any trends or variations.

This study makes a contribution to theory: first, by examining the networking behaviour of business women, without comparing their behaviour to men, the research provided insight into the underlying reasons of why these women networked the way they do. Second, it compared various types of businesses at different stages of business cycle; and business owners with different demographic and personal characteristics; thereby providing data about the impact of the nature of the business and personal demographic of business owners on networking, so future research regarding the networking behaviour of business women can benefit with better information.

The contribution to management practices was for the owners themselves. The research revealed that a challenge for women SBOs was that they often did not have access to networks and networking activities, and provided guidelines for women SBOs about more reflective networking practices, so they can participate in the right networks to help them with their business.

From a policy-maker's perspective, this research suggests they might seek to provide potential women entrepreneurs access to affordable, flexible and industry specific business functions. 


\section{REFERENCES}

Ahl H (2006) Why Research on Women Entrepreneurs Needs New Directions. Entrepreneurship Theory and Practice, September, 2006 595-621.

Allen S \& Truman C (1991) Prospects for women's businesses and self-employment in the year 2000.

In J. Curran, R. Blackburn, (Eds). Paths of Enterprise: The Future of the Small Business. London: Routledge.

Baptist M, Sanders I, Conroy K \& Norris C (2006) Exporting For The Future. Teaching Resource.

Retrieved on $01^{\text {st }}$ of March 2010 from http://www.austrade.gov.au/.

Bates T (1995) Self-employment entry across industry groups. Journal of Business Venturing 10:143156.

Bennett R \& Dann S (2000) The Changing Experience of Australian Female Entrepreneurs. Gender, Work and Organization 7(2):75-83.

Birley S \& MacMillan I (1997) Entrepreneurship in a Global Context. London: Routledge.

Breen, J. (2010). Gender differences in home-based business ownership. Small Enterprise Research, 17(2), 124-136.

Brereton D \& Jones O (2002) Examining The Entrepreneurial Process: Social Networks and Business Startups. Paper presented at the 2002 EURAM Conference, Manchester Metropolitan University, Manchester.

Brush C (1992) Research on Women Business Owners: Past Trends, A New Perspective and Future Directions. Entrepreneurship Theory and Practice 16(4): 5-26.

Brush G \& Hisrich D (1991) Antecedent influences on women-owned businesses. Journal of Managerial Psychology 6(2): 9-16.

Buttner H (1993) Female entrepreneurs: How far have they come? Business Horizons 36(2): 59-65.

Carter S \& Evans D (2006). Enterprise and Small Business: Principles, Practice and Policy (2nd ed.) Harlow: Financial Times Prentice Hall.

Carter S \& Shaw E (2006) Women's Business Ownership: Recent Research and Policy Developments. Retrieved. from http://www.bis.gov.uk/files/file38330.pdf. 
Carr M (1990) Women in Small-Scale Industries, Some Lessons from Africa. Small Enterprise Development 1(1): 47-55.

Chiu C (1998) Wives' Voices: Unequal Reward Distribution in Small Family Businesses. Southeast Asian Journal of Social Science 26(2): 33-44.

Chun B, Barrett M, St-Onge A, Firdausy C, Lee H, Zabludovsky G, Tiong-Aquino S, Lai S \& Weeks J (1999) Women Entrepreneurs in SMEs in the APEC Region: APEC Policy Level Group on Small \& Medium Enterprises.

Conway S, Jones O \& Steward F (2001) Realising the Potential of the Social Network Perspective in Innovation Studies: Imperial College Press, London.

Dana L (2001) The education and training of entrepreneurs in Asia. Education \& Training 43(8/9): 405-414.

Dann S, Bennett R, Drennan J \& Dann S (2006) Female Entrepreneurship in Australia: Revisited. Paper presented at the ANZAM 2006 Conference Proceedings, Brisbane, Queensland.

Dawson C, Fuller-Love N, Sinnott E, O'Gorman B (2011) Entrepreneurs' perceptions of business networks: does gender matter? Entrepreneurship and Innovation 12(4): 271-281.

Dhaliwal S (2000) Entrepreneurship - a learning process: the experiences of Asian female entrepreneurs and women in business. Education + Training 42(8): 445-452.

Dhaliwal S, Scott J \& Hussain J (2009) Help or Hindrance? South Asian Women in the Family Firm. Queen's University Management School Working Paper Series, MS_WPS_MAN_09_8.

Fagenson A (1993) Personal Value Systems of Men and Women Entrepreneurs Versus Managers. Journal of Business Venturing 8: 409-430.

Fischer E (1992) Sex differences and small-business performance among Canadian retailers and service providers. Journal of Small Business and Entrepreneurship 9(4): 2-13.

Gamna M, Kleiner B (2001) The old boys' network today. International Journal of Sociology and Social Policy 21(8-9): 101-107.

Granovetter M (1985) Economic action and social structure: the problem of embeddedness. American Journal of Sociology, November 55-81. 
Granovetter M (1992) Economic Institutions as Social Constructions: A Framework for Analysis.

Acta Sociologica 35: 3-11.

Gray J (1999) An Empirical Model of Small Business Success. Faculty of Business and Economics Working Paper 18/99. Victoria: Monash University.

Greve A \& Salaff J (2003) Social Networks and Entrepreneurship. Entrepreneurship, Theory \& Practice 28(1): 1-22.

Hatala J (2006) Social Network Analysis in Human Resource Development: A New Methodology. Human Resource Development Review 5(1): 45-71.

Hanson S, Blake M (2009) Gender and entrepreneurial networks. Regional Studies 43(1):135-149.

Heck R, Rowe B \& Owen A (1995) Home-Based Employment And Family Life. USA: Greenwood Publishing Group.

Hughes KD (2006) Exploring Motivation and success among Canadian women entrepreneurs. Journal of Small Business and Entrepreneurship 19(2): 107-120.

Humbert A \& Drew E (2010) Gender, entrepreneurship and motivational factors in an Irish context. International Journal of Gender and Entrepreneurship 2(2):173-196.

Kim J \& Ling C (2001) Work-Family Conflict of Women Entrepreneurs in Singapore. Women In Management Review 16(5): 2001.

Klyver K, Terjesen S (2007) Entrepreneurial network composition. Women in Management Review 22(8): 682-688.

Kraut R (1988) Homework: What Is It and Who Does It. In K. Christensen (Ed.), The New Era of Home-Base Work: Directions and Policies (pp. 30-48). Boulder: Westview Press.

Kwong C, Thompson P, Evans D \& Brooksbank D (2009) Nascent entrepreneurial activity within female ethnic minority groups. International Journal of Entrepreneurial Behaviour \& Research, 15(3): 262-281.

Lake P \& Erwee R (2005) Benefits of membership in a business networking group. Paper presented at the ANZAM 2005 Conference Proceedings, Canberra, ACT.

Low A (2008) Economic Outcomes of Female Immigrant Entrepreneurship. International Journal of Entrepreneurship and Small Business 5(3/4): 224-240. 
Mason C M, Carter S, Tagg S (2011) Invisible businesses: The characteristics of homebased businesses in the United Kingdom. Regional Studies 45(5): 625-639.

McClelland E, Swail J, Bell J \& Ibbotson P (2005) Following the pathway of female entrepreneurs. A six-country investigation. International Journal of Entrepreneurial Behaviour \& Research 11(2): 84-107.

Neergaard H, Shaw E \& Carter S (2005) The impact of gender, social capital and networks on business ownership: a research agenda. International Journal of Entrepreneurial Behaviour \& Research 11(5): 338-357.

Nijkamp P (2003) Entrepreneurship in a modern network economy. Regional Studies 37(4): 395-405.

Redmond J, Walker E (2010) Home-based business policy and return on investment for the community. Small Enterprise Research 17(2): 150-164.

Renzulli, L., Aldrich, H., Moody, J. (2000). Family Matters: Gender, Networks, and Entrepreneurial Outcomes. Social Forces, 79(2), 523-546.

Robertson P (2003) The role of training and skilled labour in the success of SMEs in developing countries. Education Training 45(8/9): 461-473.

Robson P J A, Jack S L, Freel M S (2008) Gender and the use of business advice: evidence from firms in the Scottish service sector. Environment and Planning C: Government and Policy 26:292314.

Roffey B, Stanger A, Forsaith D, McInnes E, Petrone F, Symes C \& Xydias M (1996) Women in Small Business: A Review of Research. Canberra: University of South Australia.

Sappleton S (2009) Women non-traditional entrepreneurs and social capital. International Journal of Gender and Entrepreneurship \& Regional Development 1(3): 192-218.

Shabbir A \& Gregorio S (1996) An examination of the relationship between women's personal goals and structural factors influencing their decision to start a business: The Case Of Pakistan. Journal of Business Venturing 11: 507-529.

Shaw E (2006) Small firm networking an insight into contents and motivating factors. International Small Business Journal 24(1): 5-29. 
Smith P, Smith S \& Hoy F (1992) Female business owners in industries traditionally dominated by males. Sex Roles 26(11/12): 485-496.

Sorenson R L, Folker C A, Brigham K H (2008) The collaborative network orientation: achieving business success through collaborative relationships. Entrepreneurial Theory and Practice, 32(4): 615-634.

Stanger A (2004) Gender-comparative use of small business training and assistance: a literature review. Education + Training 46(8/9): 464-473.

Stanger A, Roffey B, Forsaith D, McInnes E, Petrone F, Symes C \& Xydias M (2002) Gender differences in small business owner-managers. The International Journal of Entrepreneurship and Innovation 3(2): 93-107.

Thompson P, Jones-Evans D, Kwong C (2009) Women and Home-based Entrepreneurs: Evidence from the United Kingdom. International Small Business Journal 27(2): 227-239.

Still L, Timms W (2000) Women's business: the flexible alternative work style for women. Women In Management Review 15(5/6): 272-282.

Still L \& Walker E (2003) Women business: A changing paradigm? Women in Management Review 21(4): 294-310.

Still L \& Walker E (2006) The self-employed woman owner and her business. Women In Management Review 21(4): 294-310.

Ucbasaran D, Lockett A, Wright M \& Westhead P (2003) Entrepreneurial founder teams: factors associated with member entry and exit. Entrepreneurship Theory and Practice 28(2): 107127.

Walker E (2002) Small business owner's measures of success. Edith Cowan University, Perth.

Walker E, Wasserman S \& Welman B. (1993). Statistical models for social support networks. Sociological Methods and Research 22(1): 71-98.

Walker E \& Webster B (2007) Gender, age and self-employment: some things change, some stay the same. Women in Management Review 22(2): 122-135.

Wesman J (1995) Dive Right In - The Sharks Won't Bite: Dearborn Financial Publishing Inc. 
Wharton F \& Brunetto Y (2007) Women entrepreneurs, opportunity recognition and governmentsponsored business networks. Women in Management Review, 22(3): 187-207.

Wiklund J, Patzelt H, Shepherd D (2009) Building an integrative model of small business growth. Small Bus Econ 32: 351-374.

Winn J (2005) Women entrepreneurs: can we remove the barriers? International Entrepreneurship and Management Journal, 1(3): 381-397. 
Determinants of Business Networking Behaviour of Women in Small Businesses

\author{
Jalleh Sharafizad \\ School of Management \\ Edith Cowan University, Perth, Australia \\ Email j.sharafizad@ecu.edu.au \\ Elizabeth Walker \\ School of Management \\ Edith Cowan University, Perth, Australia
}

\author{
Alan Brown \\ School of Management \\ Edith Cowan University, Perth, Australia
}

